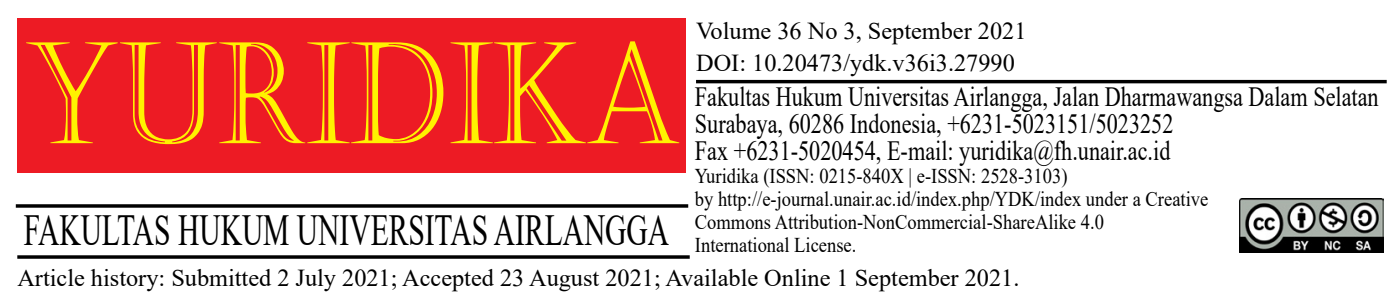

\title{
Umbrella Act as a Solution to Overcome Conflicting Regulations During the Covid-19 Pandemic
}

\author{
M. Kenza Radhya E.A and Ersya Dwi Nurifanti \\ kenzaradhyaersa@gmail.com \\ University of Pembangunan Nasional "Veteran" Jawa Timur
}

\begin{abstract}
The Covid-19 pandemic brings new challenges to people around the world, including Indonesia. In Indonesia, the Covid-19 pandemic is still an unresolved problem. As a result of the Covid-19 pandemic, besides threatening health and the economy, it is also exacerbated by government policies. Conflicting policies hinder obstacles in handling the Covid-19 pandemic. The need for a solution in the form of the formation of an umbrella act to overcome the conditions caused by the covid-19 pandemic, which covers the health and economic sectors, can be a solution to the conflicts applied by the Government, and the Umbrella Act can answer the Government's confusion in overcoming this pandemic. This study uses a normative method that discusses legal aspects by critically analyzing library materials applicable to laws and regulations. Umbrella actions can go beyond conflicting with an integrated rule. The Umbrella act can be applied in Indonesia and can be a solution to overcome the number of cases of the Covid-19 pandemic, which is still relatively high. With the Umbrella Act, the Government's responsibility will be fulfilled to provide legal protection to the community. The Umbrella Act, which has been proven to overcome conflicting regulations, will solve the current emergency. With the Umbrella Act, the Government's responsibility will fulfill to provide legal protection to society.

Keywords: Covid-19; Conflict; Regulations; Umbrella Act.
\end{abstract}

\section{Introduction}

The Covid-19 pandemic brings new challenges to people around the world, including in Indonesia. How countries prevent and prevent the spread of the virus is much broader. The Covid-19 pandemic in Indonesia is still an unsolved problem. As a result of the Covid-19 pandemic and threatening health and the economy, government policies are also exacerbated. The Covid-19 pandemic provides an impetus for a 
country to take inefficient policies to break the Covid-19 chain. ${ }^{1}$ In dealing with the Covid-19 pandemic, the Indonesian government has declared a state of emergency with the issuance of legislation Number 1 of 2020 which is still guided by Law Number 6 of 2018 concerning Health Quarantine and technical follow-up matter. With these regulations, the Government issued Government Regulation Number 21 of 2020 concerning Large-Scale Social Restrictions and the Minister of Health issued Decree of the Minister of Health Number 612/MENKES/SK/V/2010 the Guidelines for the Implementation of Health Quarantine in Handling Public Health Emergencies Concerning the World. As well as preventive efforts, the Government continues to apply the $3 \mathrm{~T}$ (Trace, Test, Treat) rules. The stipulation of an emergency status in a country can make the Government override the rights and obligations that apply under normal conditions. ${ }^{2}$ The procedural and substance aspects of state administration during the Covid-19 pandemic are also different from state administrators in normal circumstances. The state must prioritize and ensure the health of its people and ignore economic activities. According to the new Minister of Health, Budi Sadikin, "the economy will recover if people feel safe in their activities, as well as in education. It can be more effective if the pandemic problem is resolved first by the Government". ${ }^{3}$

The Covid-19 pandemic in Indonesia has not been well controlled. Instead of suppressing, the daily number of Covid-19 cases continues to increase. Data from the Task Force for the Acceleration of Handling Covid, at the beginning of May 2021, 1,691,658 cases had been added, while the addition of cases was 5,285 per day. ${ }^{4}$ The increasing number of additions shows that the rules made and applied are still not adequate. The Government is confused in dealing with this matter to prioritize between the health sector and the economy. According to the Minister

\footnotetext{
1 Lucas Bergkamp, 'State Liability for Failure to Control the COVID-19 Epidemic: International And Dutch Law' (2020) 11 European Journal of Risk Regulation.

${ }^{2}$ Lawrence O. Gostin and James G. Hodge, 'US Emergency Legal Responses to Novel Coronavirus' (2020) 323 JAMA.

${ }^{3}$ Kumparan, 'Menkes: Bukan Saya Menakuti, Tapi Vaksinasi Belum Tentu Bikin Pandemi Beres' (Kumparan, 2021) <https://kumparan.com/kumparannews/menkes-bukan-saya-menakutitapi-vaksinasi-belum-tentu-bikin-pandemi-beres-1v1kylxSjok/full> accessed 7 May 2021.

${ }^{4}$ Website COVID-19, 'Content Post | Covid19.Go.Id' (covid19.go.id, 2021) <https://covid19. go.id/berita/data-vaksinasi-covid-19-update-5-mei-2021> accessed 7 May 2021.
} 
of Finance of the Republic of Indonesia, Sri Mulyani Indrawati revealed how complicated it is to make policies to deal with the Covid-19 pandemic. He argues that "Like a dilemma, the Government faced with two choices that are difficult to sacrifice, one of which is health or the economy. There are also choices, and if one makes a choice, there are consequences. For other options. Though maybe both are important". Furthermore, the consequences of ineffective and conflicting policies will impact the failure to fulfill human rights during the Covid-19 pandemic.

Considering the Covid-19 pandemic is also an emergency, and a compelling urgency is shown by the stipulation of the Covid-19 pandemic with the Presidential Decree on Health Emergency. The Government stipulates that the Covid-19 pandemic is a 'forced crisis' with Regulation instead of Law number 1 of 2020. Therefore, it is necessary to have integrated legislation, namely the Umbrella Act, to solve complex problems in the era of the Covid-19 pandemic. Furthermore, the presence of the Umbrella Act can overcome conflicting rules during the Covid-19 pandemic and can answer the Government's confusion regarding the regulations that applied during the pandemic.

\section{Conflicting Regulation During the Covid-19 Pandemic}

Table 1. Conflicting Regulations during the covid-19 pandemic

\begin{tabular}{lll}
\hline NO & \multicolumn{1}{c}{ REGULATION } & IMPLEMENTATION \\
\hline 1. & Minister of Health Regulation No. 9 of & Article 11 paragraph (1) d of the Regulation of \\
2020 concerning PSBB Guidelines in & the Minister of Transportation No. 18 of 2020 \\
Handling Covid-19 is contrary to Minis- & stated that online motorcycle taxis could carry \\
ter of Transportation Regulation No. 18 of & passengers. Meanwhile, according to the Reg- \\
2020 concerning Transportation Control & ulation of the Minister of Health No. 9, online \\
in the Context of Preventing the Spread of & motorcycle taxis are prohibited from transport- \\
Corona Virus Disease 2019 (Covid-19). & ing passengers, which are only allowed to trans- \\
& port goods. This policy caused confusion felt by \\
& the public during the Covid-19 pandemic. ${ }^{6}$
\end{tabular}

\footnotetext{
${ }^{5}$ Soraya Novika, 'Curhat Sri Mulyani, Dilema Pilih Kesehatan Atau Ekonomi' (detikfinance, 2021) < https://finance.detik.com/berita-ekonomi-bisnis/d-5175440/curhat-sri-mulyani-dilema-pilih-kesehatan-atau-ekonomi> accessed 7 May 2021.

${ }^{6}$ Novianto Murti Hantoro, 'Konsep Omnibus Law Dan Tantangan Penerapannya Di Indonesia' (2021) II Parliamentary Review: OMNIBUS LAW < https://berkas.dpr.go.id/puslit/files/ parliamentary_review/Parliamentary Review-II-1-M-2020.pdf $>$.
} 
2. Circular Letter of the Minister of Industry The DKI Governor Regulation only exNo. 7 of 2020 concerning Business Ac- plained that only 11 sectors are allowed to tivity Permits during PSBB is contrary to operate. Meanwhile, the Minister of IndusDKI Governor Regulation No. 33 of 2020 try grants other business activities outside concerning PSBB for the Prevention of the 11 sectors mentioned in the DKI Jakarta Covid-19 Transmission. Governor Regulation. During the PSBB period, many companies violated protocol and forced to close because of the ambiguity of the regulation. ${ }^{7}$

3. Article 14 of Law no. 14 of 1989 concern- There is a lack of clarity in applying the ing Communicable Disease Outbreaks rules regarding vaccine provisions, including and Article 9 in conjunction with Arti- rights or obligations. The Government forces cle 93 of Law no. 6 of 2018 concerning the public to be vaccinated, with the threat Health Quarantine is contrary to Article of a fine that is paid if the community does 5 paragraph (3) of Law No. 36 of 2009 not want to carry out the vaccination program concerning Health and the Constitution of by the Government. This is known through 1945 the Republic of Indonesia Article 28 the Jakarta Regional Regulation No. 2 of H paragraph (1). 2020, which reads, "Everyone who deliberately refuses to treat and vaccinates against Covid-19, shall be punished with a maximum fine of Rp. 5 million". 8

4. Decree of the Minister of Health No. That the Government in this case, shows inconHK.01.07/Menkes/4239/2021 regarding sistency in implementing policies. Cutting incenthe Provision of Incentives and Death tives for health workers is a form of imperfect Compensation for health workers dealing fulfillment of responsibilities and the lack of with Covid-19 contrary to the Decree of care by the Government. Cutting incentives is the Minister of Finance Number: s-65/ unfair because these health workers have sacriMK.02/2021, decided that the Govern- ficed their lives and energy to re-stabilize nationment cut incentives for health workers by al health conditions. In fact, according to data $50 \%$, which will affect January-December in 2020, the Government still has not paid the 2021. health insurance incentive of 3.39 trillion. By cutting the incentives, it will injure the rights of-

7 ibid.;Andri Saubani, 'PSBB DKI Vs Izin Operasi Industri Yang Dikeluarkan Menperin' (Republika, 2021) <https://republika.co.id/berita/qa0126409/psbb-dki-vs-izin-operasi-industriyang-dikeluarkan-menperin> accessed 16 May 2021.

${ }^{8}$ Alghiffari Aqsa, 'Tolak Vaksinasi COVID-19 Dipidana? Begini Perspektif HAM' (Hukum Online.com, 2021) <https://www.hukumonline.com/klinik/detail/ulasan/lt600eb7f29e097/tolakvaksinasi-covid-19-dipidana-begini-perspektif-ham/> accessed 6 February 2021.;Kompas.com, 'Perda DKI Soal Denda Rp 5 Juta Bagi Penolak Vaksin Covid-19 Digugat Ke MA' Kompas.com (Jakarta, 18 December 2021) <https://megapolitan.kompas.com/read/2020/12/18/12060821/perdadki-soal-denda-rp-5-juta-bagi-penolak-vaksin-covid-19-digugat-ke-ma?page=all $>$. 
health workers, as described in Article 57 of Law no. 36 of 2014 concerning Health Workers. ${ }^{9}$

5. Presidential Instruction Number 4 In 2020 The accuracy of data on social assistance reregarding Refocusing on Budget Alloca- cipients in Indonesia during the pandemic is tion Activities and procurement of goods still considered weak and not well-targeted. and services in the context of accelerating Especially in the procurement of medical dethe handling of the corona virus. vices for health workers who are easy targets for corruption from several elements. ${ }^{10}$

6. Government Regulation in place of Acts In Article 27, the substance of the article proNumber 1 In 2020 regarding Financial vides absolute immunity for financial officials Policies and The Financial System for in making decisions so that they can be legally Handling the Corona Virus. immune. The article explains that any policy issued in good faith will be legally immune. In fact, during the COVID-19 pandemic for more than a year, it shows that many state officials have misused APBN funds for their interests, which can harm people in need. ${ }^{11}$

7. Presidential Decree Number 11 In 2020 The establishment of a state of emergency regarding the Establishment of a Covid-19 during this pandemic does not have practical Public Health Emergency. implications for its implementation in society. This is shown by the permission for China workers to enter Indonesia during the Covid-19 pandemic, and there are around 10,482 people. The Chinese foreign workers who came were using a visit visa, which is contrary to Minister of Law and Human Rights regulation Number 26 of 2021 concerning Visas and Stay Permits

${ }^{9}$ Dewi Nurita, 'Insentif Tenaga Kesehatan Covid-19 Dipotong 50 Persen, PKS Nilai Tak Manusiawi’ Tempo (Jakarta, 4 February 2021) <https://nasional.tempo.co/read/1429582/ insentif-tenaga-kesehatan-covid-19-dipotong-50-persen-pks-nilai-tak-manusiawi>.;Liputan6.com, 'Pemerintah Nunggak Rp 3,39 Triliun Insentif Tenaga Kesehatan, Kapan Dibayar?' (Liputan6.com, 2021) <https://m.liputan6.com/bisnis/read/4514523/pemerintah-nunggak-rp-339-triliun-insentiftenaga-kesehatan-kapan-dibayar> accessed 18 April 2021.

${ }^{10}$ Farih Maulana Sidik, 'KPK Ungkap Kendala Kawal Bansos: Rendahnya Kualitas Dan Transparansi Data' (Detik News, 2021) < https://news.detik.com/berita/d-5285783/kpk-ungkapkendala-kawal-bansos-rendahnya-kualitas-dan-transparansi-data $>$ accessed 17 December 2020.;Anisa Petrus, 'Kejari TTU Tahan 3 Tersangka Korupsi Pengadaan Alkes RSUD Kefamenanu' (Merdeka.com, 2021) <https://www.merdeka.com/peristiwa/kejari-ttu-tahan-3-tersangka-korupsipengadaan-alkes-rsud-kefamenanu.html> accessed 17 April 2021.

${ }^{11}$ Aditya Budiman, 'Mabes Polri Catat Ada 107 Kasus Penyalahgunaan Bansos Covid-19' Tempo (Jakarta, 4 September 2020) <https://nasional.tempo.co/read/1382860/mabes-polri-catatada-107-kasus-penyalahgunaan-bansos-covid-19>. 
in the Adaptation Period to New Habits Article 3, which explains that "The Minister temporarily suspends the granting of visa-free visits and visit visas upon arrival until the COVID-19 Pandemic is declared over by the ministry or agency that carries out the handling of COVID-19". ${ }^{2}$

Source: Analyzed from the primary source.

\section{Concept of Umbrella Act}

All regulations laws in Indonesia must be by the concept of laws and regulations as described in law number 12 of 2011 concerning laws and regulations. The presence of the Umbrella Act is not new in Indonesia. In Indonesia concepts of the Umbrella Act such as Law Number 5 of 1960 concerning Agrarian Principles, Law Number 32 of 2009 concerning Environmental Protection and Management, and the recently ratified regarding Omnibus Law, which includes the Law on Job Creation, Taxation, and empowerment of micro, small and medium business. Regarding the Umbrella Act legally in Indonesia, its position has not been regulated. As a result of the Umbrella Act, the law is a tradition of the standard law system adopted by Indonesia. The Umbrella Act Outcome Act can be comprehensively governed and then have the power over other rules.

The Umbrella Act's position can later be based on Article 7 paragraph (1) of Law Number 12 of 2011 concerning the Establishment of Legislation as amended by Law Number 15 of 2019. When viewed from this provision, the Umbrella Act is a law still domiciled under the constitution but higher than other types of legislation. Meanwhile, the umbrella act position will be in line with the Act or Regulation instead of Law. Article 10 paragraph (1) of Law Number 12 of 2011 concerning the Establishment of Legislation as amended by Law Number 15 of 2019 explains the content that must be regulated by law which must include:

\footnotetext{
${ }^{12}$ Raiza Andini, 'Kedatangan TKA China Di Masa Pandemi Bertentangan Dengan Kebijakan Jokowi’ (RMOL.ID, 2021) < https://politik.rmol.id/read/2021/05/27/489580/kedatangan-tka-chinadi-masa-pandemi-bertentangan-dengan-kebijakan-jokowi $>$ accessed 6 June 2021
} 
1) Further regulation regarding the provisions of the 1945 Constitution of the Republic of Indonesia;

2) The order of law to be regulated by law;

3) Ratification of certain international agreements;

4) Follow up on the decision of the Constitutional Court;

5) Fulfillment of legal needs in society.

Based on article 10 paragraph (1), it shows that legal norms as content material in the form of articles do not change the legal norms that already exist in the previous law. Suppose it is related to the provisions regarding the material content of the law. ${ }^{13}$ The existence of the Umbrella Act will not conflict with Law Number 15 of 2019 and its amendments if the content material regulated in the Umbrella Act is by the provisions of the law. In addition, there is no prohibition in Law No. 15 of 2019 and its amendments for the formation of the Umbrella Act, which functions to accommodate several cargo materials at once. The general principles that need to be considered by law drafters are the outline of policies outlined in the law through comprehensive and comprehensive outline building. The product of the law must be clear and functional, considering the interests of the parties to be regulated or those who will implement it. The legislation refers to the need or meets the objectives that formulated, efficient or avoided cross-shows. ${ }^{14}$

\section{Formation of the Umbrella Act to Overcome Conflicting Regulation During the Covid-19 Pandemic}

Public Policy is the elaboration of laws and regulations used by the Government to run the state administration machine properly so that problems related to the sectors most affected are during the pandemic, namely the economic and health sectors can be resolved, so that civil society lives dynamically, as well as government public services. Well, for the advancement of the life of the nation and state in the Republic of Indonesia. Those three things must be considered by anyone who is a state administrator. All public policies that have emerged since

\footnotetext{
${ }^{13}$ Umbu Rauta, Konstitusionalitas Pengujian Peraturan Daerah (Genta Publishing 2016).[94].

${ }^{14}$ Jimly Asshiddiqie, Perihal Undang-Undang (Rajawali Pers 2010).[235].
} 
the Covid-19 pandemic are largely unfocused and violate Law number 12 of 2011 concerning the Establishment of Legislation as amended by Law Number 15 of 2019. It is one of the reasons why it is difficult for Indonesia to control the Covid-19 pandemic. Many of the implementations of the Act are overlapping, ambiguous, conflicting, making them difficult to implement. During the Covid-19 pandemic, several Government Regulations, Presidential Regulations, Ministerial Regulations or Agency Head Regulations, Ministerial Decrees or Agency Head Decrees, and even Circular Letters emerged. The existence of statutory regulations is generally by Law number 12 of 2011 except for the existence of Circular Letters. Based on Article 7 of Law number 12 of 2011, the Circular Letters are not listed. So Circular Letters are not a legal product but only an internal regulation of the Ministry or Agency. In terms of handling Covid-19, the problem of conflict in policy implementation is one of the main causes of difficulty in dealing with the Covid-19 pandemic. The explosion of positive Covid-19 cases in May 2021 is approaching 14,000 people per day. ${ }^{15}$ It means that the growth of positive Covid-19 patients is still increasing. Very worrying numbers, and there must be a proper policy to deal with it.

The urgency of forming the Umbrella Act could be seen by reflecting on the implementation of regulations implemented by the Government during the Covid-19 pandemic. Several conflicting regulations cause problems and have an impact on handling the pandemic. Many parties consider that the Government is less responsive in dealing with the pandemic, the failure of coordination and communication of risks provided by the Government to the society regarding how people should adapt to the pandemic situation, which creates a low-risk perception and makes individual alert reduced to the dangers of Covid-19. This is reflected in several regulations passed during the pandemic, which conflict in a substance due to the absence of legal infrastructure in dealing with the pandemic, especially Covid-19, which is a fundamental factor causing this outbreak to be chaotic and not integrated. Considering the Covid-19 pandemic is a pressing urgency with the

\footnotetext{
${ }^{15}$ Website COVID-19 (n 4).
} 
issuance of Regulation instead of Law Number 1 of 2020 and the establishment of an emergency status as indicated by Presidential Decree Number 11 of 2020, the Government must be serious in handling the phenomenon of the Covid-19 pandemic, where the number of cases of the Covid-19 pandemic is still relatively high, and do not know when this pandemic will end. Therefore, the presence of the Umbrella Act is significant, and there is a need for regulations that can represent all the aspirations of the community. On the other hand, the Umbrella Act can overcome government confusion during the Covid-19 pandemic and is a form of government responsibility to provide legal protection to the public. Therefore, this Umbrella Act will become formal legitimacy in handling the current pandemic.

The implementation of this regulation will become a guideline and orientation for the legislation below it later, and no exception for the statutory regulations, which have related contents with Umbrella Act. Furthermore, the Umbrella Act's principle will be an estuary for the statutory regulations under it as a technical implementer. The fundamental legal framework in the Umbrella Act can minimize discrepancies between the various relevant laws and regulations. In Indonesia, the reason for the Umbrella act formed because many regulations are contradicting with the other regulations. The Umbrella Act could simplify the problems about conflicting the applied regulations by the Government. On the other side, the various published regulations during the Covid-19 pandemic were only limited to try to fulfill the constitutional aspects listed in Article 12 and Article 22 of the 1945 Constitution of the Republic of Indonesia. However, at the implementations, many of regulations are not following statutory regulation and other statutory regulation. ${ }^{16}$ On the other side, the Umbrella act is a strategic step in the rule's implementation aspects adapted to the evolving circumstances. The Umbrella Act related to the emergency state of law because of the Covid-19 pandemic will answer society's doubts about the uncertainty in the laws and regulations that the Government has implemented during the current emergency. The general description in the Umbrella Act should be explained in detail to provide additional information.

\footnotetext{
${ }^{16}$ Fradhana Putra Disantara, 'Tanggung Jawab Negara Dalam Masa Pandemi Covid-19' (2020) 6 Jurnal Cendekia Hukum.
} 
Regarding the contents of the Umbrella Act itself, it will relate to matters that regulate the health and economic sectors from the mitigation process, things that are allowed and prohibited, and the process of fulfilling society rights during the pandemic. In addition, the presence of the Umbrella Act in the Indonesian constitution can also break the convoluted bureaucratic chain, which in Indonesian politics, the presence of the Umbrella Act can be a "cure" for inter-institutional sectoral ego disease, which expected to create coordination between institute in overcoming conflicts with effective and efficient forms of regulation. The regulation in this concept is to make a new law to amend several laws at once. Still, in terms of making, there is no difference in making laws in general. Still, the substance is firm to revoke or amend several related laws considered complicated, conflicting, and ineffective. ${ }^{17}$

Then, it can be said that the Umbrella Act is a method or concept of making regulations that combine several rules of a different substance into an extensive regulation that functions as an integrated regulation. If the regulation is promulgated, the consequence will be to revoke several rules resulting from the merger, and their substance will be declared invalid, either in part or in whole.

\section{Conclusion}

In terms of handling Covid-19, the problem of conflict in policy implementation is one of the main causes of difficulty in dealing with the Covid-19 pandemic. The presence of the Umbrella Act is very important, there is a need for regulations that can overcome the conflicting regulations that have been implemented by the Government during the Covid-19 pandemic. On the other side, Umbrella Act could overcome the Government confusion during the pandemic and is a form of government responsibility to provide legal protection to the society. The Umbrella Act will become formal legitimacy in handling the pandemic now day and could become a reference when a pandemic occurs again. The government in

\footnotetext{
${ }^{17}$ Novianto Murti Hantoro (n 6).
} 
terms of handling the pandemic must be serious by being declared an emergency. The government can establish the Umbrella Act which has been proven to be able to overcome conflicting rules into an integrated regulation. Thus, conflicting regulations and the number of cases of the Covid-19 pandemic can be resolved.

\section{Bibliography}

Aditya Budiman, 'Mabes Polri Catat Ada 107 Kasus Penyalahgunaan Bansos Covid-19' Tempo (Jakarta, 4 September 2020) < https://nasional.tempo.co/ $\mathrm{read} / 1382860 / \mathrm{mabes}-$ polri-catat-ada-107-kasus-penyalahgunaan-bansoscovid-19>.

Alghiffari Aqsa, 'Tolak Vaksinasi COVID-19 Dipidana? Begini Perspektif HAM' (Hukum Online.com, 2021) <https://www.hukumonline.com/klinik/ detail/ulasan/lt600eb7f29e097/tolak-vaksinasi-covid-19-dipidana-beginiperspektif-ham/> accessed 6 February 2021.

Andri Saubani, 'PSBB DKI Vs Izin Operasi Industri Yang Dikeluarkan Menperin' (Republika, 2021) <https://republika.co.id/berita/qa0126409/psbb-dki-vsizin-operasi-industri-yang-dikeluarkan-menperin> accessed 16 May 2021.

Anisa Petrus, 'Kejari TTU Tahan 3 Tersangka Korupsi Pengadaan Alkes RSUD Kefamenanu' (Merdeka.com, 2021) < https://www.merdeka.com/peristiwa/ kejari-ttu-tahan-3-tersangka-korupsi-pengadaan-alkes-rsud-kefamenanu. html $>$ accessed 17 April 2021.

Dewi Nurita, 'Insentif Tenaga Kesehatan Covid-19 Dipotong 50 Persen, PKS Nilai Tak Manusiawi’ Tempo (Jakarta, 4 February 2021) < https://nasional.tempo. $\mathrm{co} / \mathrm{read} / 1429582 /$ insentif-tenaga-kesehatan-covid-19-dipotong-50-persenpks-nilai-tak-manusiawi $>$.

Farih Maulana Sidik, 'KPK Ungkap Kendala Kawal Bansos: Rendahnya Kualitas Dan Transparansi Data' (Detik News, 2021) <https://news.detik.com/ berita/d-5285783/kpk-ungkap-kendala-kawal-bansos-rendahnya-kualitasdan-transparansi-data $>$ accessed 17 December 2020.

Fradhana Putra Disantara, 'Tanggung Jawab Negara Dalam Masa Pandemi Covid-19' (2020) 6 Jurnal Cendekia Hukum.

Jimly Asshiddiqie, Perihal Undang-Undang (Rajawali Pers 2010).

Kompas.com, 'Perda DKI Soal Denda Rp 5 Juta Bagi Penolak Vaksin Covid-19 Digugat Ke MA' Kompas.com (Jakarta, 18 December 2021) <https:// 
megapolitan.kompas.com/read/2020/12/18/12060821/perda-dki-soal-dendarp-5-juta-bagi-penolak-vaksin-covid-19-digugat-ke-ma?page=all $>$.

Kumparan, 'Menkes: Bukan Saya Menakuti, Tapi Vaksinasi Belum Tentu Bikin Pandemi Beres' (Kumparan, 2021) <https://kumparan.com/kumparannews/ menkes-bukan-saya-menakuti-tapi-vaksinasi-belum-tentu-bikin-pandemiberes-1v1kylxSjok/full> accessed 7 May 2021.

Lawrence O. Gostin and James G. Hodge, 'US Emergency Legal Responses to Novel Coronavirus' (2020) 323 JAMA.

Liputan6.com, 'Pemerintah Nunggak Rp 3,39 Triliun Insentif Tenaga Kesehatan, Kapan Dibayar?' (Liputan6.com, 2021) <https://m.liputan6.com/bisnis/ $\mathrm{read} / 4514523 /$ pemerintah-nunggak-rp-339-triliun-insentif-tenagakesehatan-kapan-dibayar> accessed 18 April 2021.

Lucas Bergkamp, 'State Liability for Failure to Control the COVID-19 Epidemic: International And Dutch Law’ (2020) 11 European Journal of Risk Regulation.

Novianto Murti Hantoro, 'Konsep Omnibus Law Dan Tantangan Penerapannya Di Indonesia' (2021) II Parliamentary Review: OMNIBUS LAW < https:// berkas.dpr.go.id/puslit/files/parliamentary_review/Parliamentary Review-II1-M-2020.pdf>.

Raiza Andini, 'Kedatangan TKA China Di Masa Pandemi Bertentangan Dengan Kebijakan Jokowi' (RMOL.ID, 2021) <https://politik.rmol. $\mathrm{id} / \mathrm{read} / 2021 / 05 / 27 / 489580 /$ kedatangan-tka-china-di-masa-pandemibertentangan-dengan-kebijakan-jokowi > accessed 6 June 2021.

Soraya Novika, 'Curhat Sri Mulyani, Dilema Pilih Kesehatan Atau Ekonomi' (detik finance, 2021) $<$ https://finance.detik.com/berita-ekonomi-bisnis/d-5175440/ curhat-sri-mulyani-dilema-pilih-kesehatan-atau-ekonomi> accessed 7 May 2021.

Umbu Rauta, Konstitusionalitas Pengujian Peraturan Daerah (Genta Publishing 2016).

Website COVID-19, 'Content Post | Covid19.Go.Id' (covid19.go.id, 2021) <https:// covid19.go.id/berita/data-vaksinasi-covid-19-update-5-mei-2021> accessed 7 May 2021.

HOW TO CITE: M. Kenza Radhya E.A and Ersya Dwi Nurifanti, 'Umbrella Act as a Solution to Overcome Conflicting Regulations During the Covid-19 Pandemic' (2021) 36 Yuridika. 